\title{
Life history and larval performance of the Peacock pansy butterfly, Junonia almana Linnaeus (Lepidoptera: Rhopalocera: Nymphalidae)
}

\author{
${ }^{1}$ Bhupathi Rayalu. M, ${ }^{2}$ Ella Rao. K, ${ }^{3}$ Sandhya Deepika.D, ${ }^{4}$ Atluri. J.B \\ 1,2,3,4 (Department of Botany, Andhra University, Visakhapatnam-530 003, Andhra Pradesh, India.)
}

\begin{abstract}
The life history of the Peacock pansy butterfly, Junonia almana and larval performance in terms of food consumption and utilization, and the length of life cycle on its host plant Ruellia tuberosa are described for the first time. The study was conducted during 2008 at Visakhapatnam $\left(17^{\circ} 42^{\prime} N\right.$ and $82^{\circ} 18^{\prime}$ E), South India. Junonia almana completes its life cycle in $24.40 \pm 1.14$ days (eggs 3, larvae, $15-16$, pupa $5-7$ days). The values of nutritional indices across the instars were AD (Approximate Digestibility) 44.10 - 95.87\%; ECD (Efficiency of Conversion of Digested food) $1.48-34.00 \%$; ECI (Efficiency of Conversion of Ingested food) $1.41-15.00 \%$, measured at the temperature of $28 \pm 2^{\circ} \mathrm{C}$ and $\mathrm{RH}$ of $80 \pm 10 \%$ in the laboratory. These relatively high values of ECD and ECI explain at least partially the ecological success of J. almana in the present study environment.
\end{abstract}

Keywords: Life history, Junonia almana, captive rearing, immature stages, food utilization indices.

\section{Introduction}

Butterflies are known for the incontestable beauty of their wing colors, and contribute to the aesthetic quality of the environment. They constitute an important pollinator resource, and on this account their conservation management has become a global risk $[1,2]$. Little has been said by conservationists about the conservation of butterflies, which are worthy of protection [3]. To consider any conservation management programme accurate life history information of all butterflies in an area is required. Such knowledge in most cases of Indian butterflies is seriously inadequate [4,5]. Sincere efforts in this direction have been in action for the butterflies of South India [6,7,8]. We describe here the details of immature stages, larval performance on its host plant Ruellia tuberosa L. and the length of the life cycle from egg to adult eclosion for the Peacock pansy butterfly, Junonia almana Linnaeus.

\section{Materials And Methods}

The present study was carried out at Visakhapatnam during the calendar year 2008. Visakhapatnam $\left(17^{\circ} 42^{\prime} \mathrm{N}\right.$ latitude and $82^{\circ} 18^{\prime} \mathrm{E}$ longitude) is located on the east coast of India in the State of Andhra Pradesh. The basic protocol for captive rearing is to collect eggs from wild-mated females, rear larvae to adult butterflies in captivity, and release adult butterflies and/or pupae back into wild populations [9]. The reproductive activity of the Peacock pansy butterfly, Junonia almana was observed regularly during 0800 to $1500 \mathrm{~h}$ at two sites viz. Andhra University campus and the Zoo Park area, $5 \mathrm{~km}$ away from the campus. Once adult butterflies were located detailed observations were made in order to observe the period of copulation and oviposition. After detecting ovipositions, the leaf with eggs was collected in Petri dishes $(15 \mathrm{~cm} \times 2.5 \mathrm{~cm}$ depth) and brought to the laboratory. The leaf piece with eggs was then placed in a smaller Petri dish $(10 \mathrm{~cm} \times 1.5 \mathrm{~cm}$ depth), that was lined with moistened blotter to prevent leaf drying. Such Petri dishes were kept in a clean, roomy cage fitted with wire gauge. Since ants were never detected, no special protection device was tried to avoid predation of eggs. They were examined regularly at $6 \mathrm{~h}$ interval for recording the time of hatching. Each of the freshly emerged larvae was transferred to a clean Petri dish lined with moistened blotter with the help of a camel hairbrush. The larvae were supplied daily with weighed quantity of tender leaf pieces of the host plant. The faeces and the leftover of the food was collected and weighed each day $(24 \mathrm{~h})$. The growing larvae were observed regularly to note the change of instar, and characters including length, breadth and weight measurements. As the larvae grew, they needed more space. Hence, increased space was provided by transferring the growing larvae to bigger Petri dishes $(15 \mathrm{~cm} \times 2.5 \mathrm{~cm}$ depth). Larval performance in terms of food utilization indices were calculated as described by Waldbauer [10].

Five replications were maintained for the study of all parameters. Fresh weight measurements were used for the purpose. The development of pupa from full grown larva and particulars of pupa including color, shape, size, weight and the time of adult eclosion were also recorded. Millimetre graph paper was used for taking measurements. The laboratory temperature was $28 \pm 2^{\circ} \mathrm{C}$ and relative humidity $80 \pm 10 \%$ with normal 
Life history and larval performance of the Peacock pansy butterfly, Junonia almana Linnaeus

indirect sunlight conditions that varied in duration between $12 \mathrm{~h}$ during November/ January and $14 \mathrm{~h}$ during June/July.

In describing the details of adult characters, the butterflies that have emerged from the pupae in the laboratory, and those caught in the wild were used.

\subsection{Adult stage (Fig. 1a)}

\section{Results}

Upperside of both wings tawny. There are two large eye-spots near the apex of hindwings, and two smaller spots on each of its forewings. Spots are also found on underside of the wings. Margins of the wings are dark brown and wavy. Head, thorax and abdomen are orangish brown. Wingspan is between $60-65 \mathrm{~mm}$. Mating and oviposition took place during $0900-1400 \mathrm{~h}$.

\subsection{Adult female behavior during oviposition}

The gravid female laid eggs singly on the underside of the young and mature leaves of Ruellia tuberosa. About $8-12$ eggs were laid at a time but on different leaves. Adults were found probing for nectar on the Lantana camara L, Tridax procumbens L., Calotropis gigantea (L.) R.Br., and Rostellularia procumbens (L.) Nees.

\subsection{Egg stage (Fig 1b)}

The eggs were green, spherical with longitudinal ridges and shining. Measured $0.90-1.00(0.96 \pm$ $0.05) \mathrm{mm}$ in height. They hatched in 3 days of incubation. Immediately after hatching, the larva ate its egg-shell. It passed through five distinct instars over a period of $15-16(15.80 \pm 0.45)$ days.

\subsection{Larval stage (Fig. 1c-g)}

Instar I lasted for $3-6(4.40 \pm 1.14)$ days. On the first day of hatching, the instar measured $2.00-2.50$ $(2.26 \pm 0.18) \mathrm{mm}$ in length. It grew to $2.70-3.40(2.94 \pm 0.27) \mathrm{mm}$ in length, and $0.80-0.90(0.86 \pm 0.04) \mathrm{mm}$ in width. Head capsule black in color and measured $0.70-1.80(1.14 \pm 0.48) \mathrm{mm}$ in diameter. The body was light chocolate in color and covered with black hairs. Body was clearly segmented. Instar II lasted for $1-3$ $(2.20 \pm 0.84)$ days. The larva attained a length of $4.00-7.30(5.06 \pm 1.29) \mathrm{mm}$ and a width $1.00-1.50(1.13 \pm$ $0.21) \mathrm{mm}$. Head capsule measured $2.20-2.40(2.26 \pm 0.09) \mathrm{mm}$ in diameter. Color of the body turned into thick chocolate color and shining. Instar III lasted for $2-3(2.20 \pm 0.45)$ days. The larva attained a length of $6.30-$ $14.50(8.46 \pm 3.44) \mathrm{mm}$ and a width $1.20-3.80(2.72 \pm 0.70) \mathrm{mm}$. Head capsule measured $2.00-3.80(2.72 \pm$ $0.70) \mathrm{mm}$ in diameter. Body was cylindrical and shining. Hairs were clearly visible and black in color. Hairs branched and the pattern of arrangement was with six rows of hairs along the body length and 12 rows across the body. Instar IV lasted for $1-3(2.20 \pm 0.84)$ days. The larva attained a length of $9.00-17.00(13.70 \pm 2.93)$ $\mathrm{mm}$ and a width $1.80-3.20(1.02 \pm 0.04) \mathrm{mm}$. Head capsule was black and hairy and measured $3.80-4.30$ $(4.10 \pm 0.20) \mathrm{mm}$ in diameter. Body was chocolate in color and shining. Hair bases on the body were surrounded by orange colored ring like spots. Instar V lasted for $4-6(4.80 \pm 1.09)$ days. The larvae reached to a length of $28.00-31.25(28.89 \pm 1.95) \mathrm{mm}$ and a width of $3.50-4.60(3.96 \pm 0.54) \mathrm{mm}$. Head capsule measured $7.50-8.10(7.78 \pm 0.28) \mathrm{mm}$ in diameter. Color of the body turned into black and at later stage blackish-grey. Hairs also turned into grayish. There was a light black mid-dorsal streak. The bases of the hairs were grey in color. Just behind the head (neck) there was a band of creamy yellowish color. Larva stop feeding and body contracted before pupation.

\subsection{Pupal stage (Fig. 1h)}

Pupal stage lasted for $5-7(5.60 \pm 0.89)$ days. It was $16.00-19.00(17.70 \pm 1.09) \mathrm{mm}$ in length and $5.50-6.00(5.60 \pm 0.22) \mathrm{mm}$ in width at its broadest point. Pupa was thick chocolate in color. On wing cases there appeared black and cream colored markings. On dorsal side 3 longitudinal rows of small spiny projections with 8 spiny projections in each row. The color of these projections was half thick chocolate and another half cream colored. Pupa was rough to touch. Its weight was about $334.90-441.10(400.64 \pm 42.13) \mathrm{mg}$.

\subsection{Duration of life cycle}

The total development time from egg to adult eclosion ranged between $23-26$ (24.40 \pm 1.14$)$ [Egg: 3; Larva: 15-16; Pupa: 5-7] days.

\subsection{Food consumption, growth and utilization}

Table 1 gives the data on the amount of food consumed by each of the five instars and the corresponding data on weight gained by different instars. Of the total amount of food consumed, the percentage shares of successive instars were $1.03,1.43,5.14,11.79$ and $80.61 \%$ and the proportions of weight gained in relation to total weight gained by the successive instars were $0.10,0.74,3.95,9.05$, and $86.16 \%$. Thus, there was 

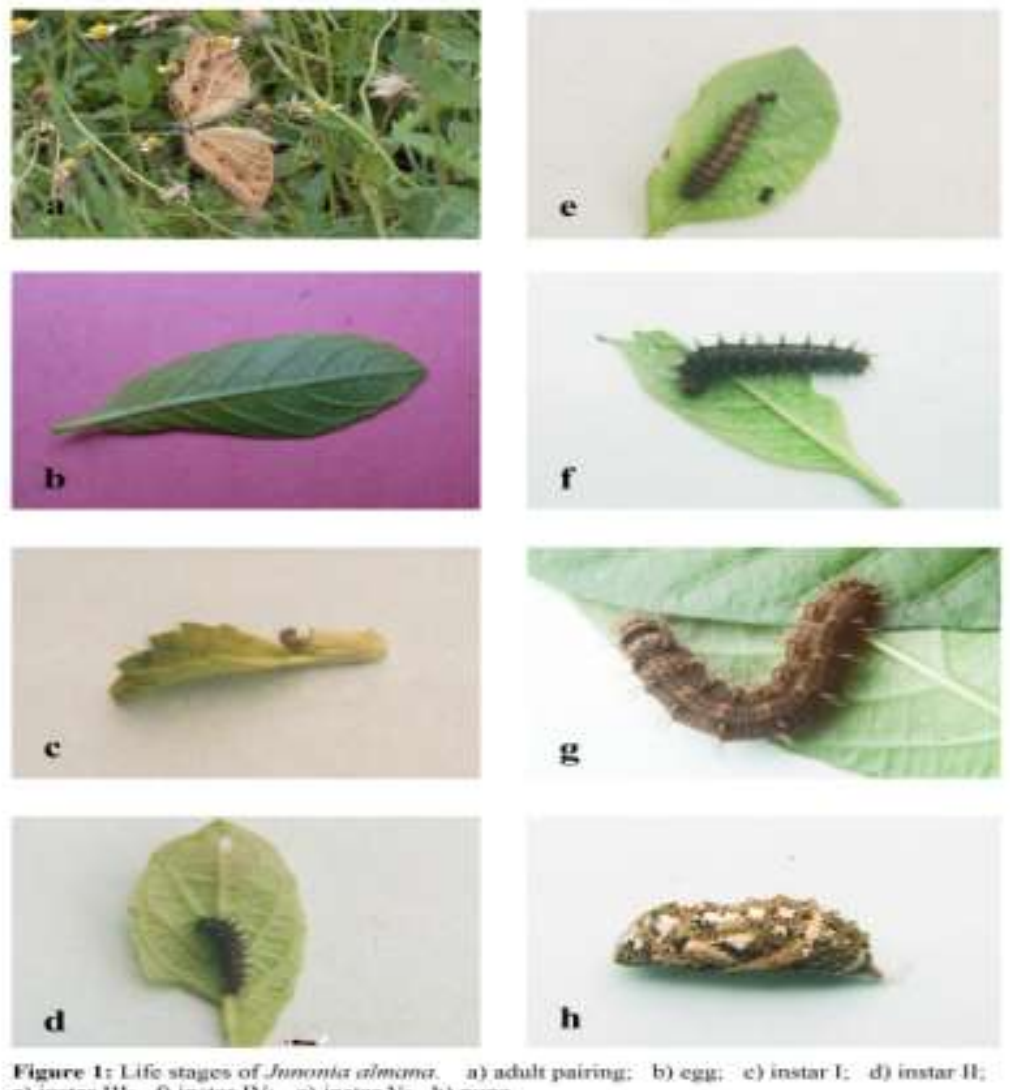

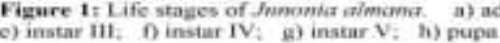

over $92 \%$ of the total food consumption and $95 \%$ of total weight gained in the fourth and fifth instars together. There was a direct relationship between food consumption and growth across the five instars (Fig. 2). The values of growth rate (GR) increased till instar III and then decreased to instar V, and consumption index (CI) progressively decreased from instar to instar. The values of GR varied between $0.14-0.37 \mathrm{mg} / \mathrm{day} / \mathrm{mg}$ and those of CI between $1.19-10.14 \mathrm{mg} /$ day/mg. Table 1 also included the data on AD, ECD, and ECI. The values of $\mathrm{AD}$ from instar to instar decreased from a high of $95.87 \%$ in first instar to a low of $44.10 \%$ in the last instar. The values of ECD and ECI increased progressively from the first instar to the last instar. The values of ECD varied from $1.48-34.00 \%$ and those of ECI from $1.41-15.00 \%$. Thus there was an inverse relationship between the values of $\mathrm{AD}$ and those of ECD and ECI.

\section{Discussion}

The total development time from egg laying to adult eclosion was $24.40 \pm 1.14$ days at about $28 \pm 2^{0} \mathrm{C}$. This behavior is in line with the expectations of short life cycles in tropical butterflies [3]. Since temperature influences instar duration and the overall development time [11,12,13,14], the duration of life cycle may vary from our records depending on the prevailing temperatures. As no temperature extremities occur at Visakhapatnam, the duration of life cycle did not vary much over the overlapping seasons.

Over the entire period of its growth, a larva consumed on average over $4.95 \mathrm{~g}$ of leaf material, with increased consumption in the last two instars. This tendency of greater consumption by the last two instars has been reported in lepidopterous larvae in general $[10,11,12,15,16,17]$, and it compensates the energy expenditure of non-feeding pupal stage [18]. The values of CI are near to the range $(0.27-6.90)$ predicted for forb foliage chewers [19]. Food consumption rate depends on the conversion efficiency of ingested food to biomass (ECI), the rate increasing as the conversion efficiency decreases or vice versa [19]. In this sense, the high CI value (10.14) of instar I is probably due to low conversion efficiency and this character is reflected in the low values of ECI for instar I compared to other successive instars. Higher growth rates occur with penultimate than with final instars [20]. The GRs of penultimate and final instars of Junonia almana are in line with the above decreasing

trend. 
IOSR Journal of Environmental Science, Toxicology and Food Technology (IOSR-JESTFT)

ISSN: 2319-2402, ISBN: 2319-2399. Volume 1, Issue 2 (Sep-Oct. 2012), PP 17-21

www.iosrjournals.org

\section{TABLE 1: Food consumption, growth and food utilization efficiencies of Junonia almana larva} fed with Ruellia tuberosa leaves.

\begin{tabular}{|c|c|c|c|c|c|c|c|c|}
\hline $\begin{array}{l}\text { Instar } \\
\text { number }\end{array}$ & $\begin{array}{l}\text { Wt. of food } \\
\text { ingested }(\mathrm{mg})\end{array}$ & Wt. of faeces (mg) & $\begin{array}{l}\text { Wt. gained by } \\
\text { larva }(\mathrm{mg})\end{array}$ & $\begin{array}{c}\text { GR } \\
(\mathrm{mg} / \mathrm{day} / \mathrm{mg})\end{array}$ & $\underset{(\mathrm{mg} / \mathrm{day} / \mathrm{mg})}{\mathrm{CI}}$ & $\begin{array}{l}\mathrm{AD} \\
(\%)\end{array}$ & $\begin{array}{l}\text { ECD } \\
(\%)\end{array}$ & $\begin{array}{l}\text { ECI } \\
(\%)\end{array}$ \\
\hline I & $50.86 \pm 08.53$ & $2.10=00.92$ & $0.72 \pm 0.05$ & 0.14 & 10.14 & 95.87 & 01.48 & 01.41 \\
\hline II & $70.82 \pm 08.82$ & $6.62 \pm 01.26$ & $5.16 \pm 0.58$ & 0.37 & 08.10 & 94.11 & 04.88 & 04.59 \\
\hline III & $254.86 \pm 22.14$ & $17.84=03.12$ & $27.46 \pm 2.45$ & 0.37 & 03.43 & 93.00 & 11.58 & 10.77 \\
\hline IV & $584.23 \pm 20.24$ & $70.92=10.41$ & $62.96 \pm 3.12$ & 0.29 & 02.74 & 87.86 & 12.26 & 10.78 \\
\hline V & $3993.68=98.43$ & $2234.66=84.52$ & $599.52=8.46$ & 0.17 & 01.19 & 44.10 & 34.00 & 15.00 \\
\hline
\end{tabular}

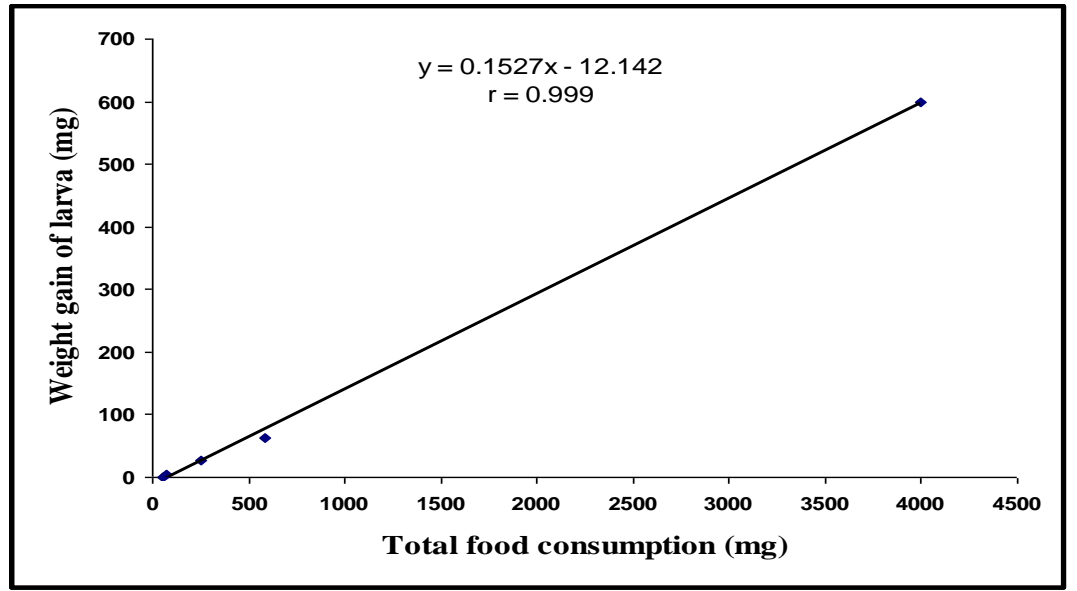

Figure 2: Relationship between food consumption and growth in Junonia almana on Ruellia tuberose

The values of $\mathrm{AD}$ that were obtained in this study are comparable with the range of $\mathrm{AD}$ values (19$81 \%$ ) for lepidopterous larvae [21]. The average $\mathrm{AD}$ percentage is over 82.99 and this high $\mathrm{AD}$ substantiates the statement of Slansky and Scriber [19] that foliage chewers often attain high AD values. Such high AD values also are expected when food item is rich in nitrogen (and also water) [21]. Similar results were repeated with Pieris brassicae (L.) [22], Euploea core (Cramer) [23], Ariadne merione merione (Cramer) [8], and Byblia ilithyia Drury [24].

The values of ECD increase from early to last instars [19]. Such trend is observed with the ECDs of Junonia almana, with the lowest value in instar I and the highest in instar V. The ECDs obtained are low compared to the ADs and such low values are not unusual [10]. This is indicative of low efficiency of conversion of digested food to body tissues. This poor utilization of food is often attributed to deficiency in some essential nutrient in food [25] or a factor causing an increase in energy expenditure on metabolism [26]. The pattern of ECI values followed closely the pattern of ECD. The values $(1.41-15.00)$ obtained are comparable with the range of values expected for forb foliage chewers $(1-78 \%)$ [19]. The pattern of ECI followed that of $\mathrm{AD}$ as suggested by Waldbauer [10]. The values of ECD and ECI, particularly those of the last two instars, are also relatively high $(12.26,34.00 ; 10.78,15.00)$, thus indicating tissue growth efficiency respectively, and ecological growth efficiency, which enabled Junonia almana to thrive successfully in the present study environment.

The information on the oviposition, larval host and larval performance in terms of food consumption, growth and utilization, and the length of life cycle from egg to adult eclosion of Junonia almana in the present study may be profitably utilized in the successful conservation management of this butterfly species either in parks, Zoos and butterfly houses well planted with flowering plants and with patches of shades. 


\section{Acknowledgements}

This paper is dedicated to the memory of our beloved teacher and mentor, Late Prof. C. Subba Reddi, who worked about 25 years on butterfly ecology. The authors sincerely thank University Grants Commission (UGC), New Delhi for financial support in carrying out this piece of work.

\section{References}

[1] T.R. New, R.M. Pyle, C.D. Thomas, and P.C. Hammona, Butterfly conservation and management, Annual Review of Entomology, $40,1995,57-83$.

[2] J. Withgott, Pollination migrates to top of conservation agenda, Bioscience, 49 (11), 1999, $857-862$.

[3] D.F. Owen, Tropical Butterflies (Clarendon Press, Oxford, 1971).

[4] T. Gay, I.D. Kehimkar, and J.C. Punetha, Common Butterflies of India (Oxford University Press, Bombay, 1992).

[5] K. Gunathilagaraj, T.N.A. Perumal, K. Jayaram, and M. Ganesh Kumar, Field guide. Some South Indian Butterflies (NilgiriWildlife and Environment Association, Udhagamandalam, India, 1998).

[6] J.B. Atluri, C. Subba Reddi, and S.P. Venkata Ramana, Life history parameters and larval performance of some south Indian butterfly species, Journal of Bombay Natural History Society 101, 2004, 96-105.

[7] B. Samatha, M. Bhupathi Rayalu, J.B. Atluri, and C. Subba Reddi, Life history and larval performance of the Psyche butterfly Leptosia nina (Rhopalocera: Pieridae). National Academi Science Letters, 31, 2008, 45-49.

[8] J.B. Atluri, B. Samatha, M. Bhupathi Rayalu, D. Sandhya Deepika, and C. Subba Reddi, Ecobiology of the common castor butterfly Ariadne merione merione (Cramer) (Lepidoptera: Rhopalocera: Nymphalidae). Journal of Research on the Lepidoptera, 42 , 2010, $13-20$

[9] E.E. Crone, D. Pickering, and C.B. Schultz, Can captive rearing promote recovery of endangered butterflies? An assessment in the face of uncertainity. Biological Conservation, 139, 2007, $103-112$.

[10] G.P. Waldbauer, The consumption and utilization of food by insects, in Beament, Treherne, and Wigglesworth (Eds) Advances in insect physiology, (London and New York: Academic Press, 1968) 229-288.

[11] S. Mathavan and T.J. Pandian, Effect of temperature on food utilization in the monarch butterfly Danaus chrysippus, Oikos, 26, $1975,60-64$

[12] S. Palanichamy, R. Ponnuchamy, and T. Thangaraj, Effect of temperature on food intake, growth and conversion efficiency of Eupterote mollifera (Insecta: Lepidoptera), Proceedings of the Indian Academi of Sciences (Animal Science), 91, 1982,417 - 422.

[13] M. Pathak and P.Q. Pizvi, Age specific survival and fertility table Papilio demoleus at different set of temperatures and host plants, Indian Journal of Entomology, 65(1), 2003, 123 - 126.

[14] M.F. Braby, Effect of temperature on development and survival in Delias nigrina (Fabricius) (Lepidoptera: Pieridae), Australian Journal of Entomology, 42(2), 2003, 138 - 143.

[15] J.M. Scriber and F.J. Slansky, The nutritional ecology of immature insects, Annual Review of Entomology, $26,1981,183$ - 211.

[16] R. Selvasundaram, Food utilization and bioenergetics of Caloptilia theivora (Walsingham) (Lepidoptera : Garcillariidae) infesting tea, Hexapoda, 4(2), 1992, $119-128$.

[17] D. Gosh and S. Gonchaudhuri, Biology and food utilization efficiency of Pericallia ricini (Fab.) (Lepidoptera: Arctiidae) in Tripura, Uttar Pradesh Journal of Zoology, 16(3), 1996, 109 - 112.

[18] T.J. Pandian, Food intake and energy expenditure patterns in two insect primary consumers, Current Science, 42, $1973,423-425$.

[19] F. Slansky and J.M. Scriber, Food consumption and utilization. in G.A. Kerkuit and L.I. Gilbert, (Eds) Comprehensive Insect Physiology, Biochemistry and Pharmacology. (Oxford: Pergamon, 1985) 85 - 163.

[20] J.M. Scriber and P. Feeny, Growth of herbivorous caterpillars in relation to feeding specialization and to the growth form of their food plants, Ecology, 60, 1979, $829-850$.

[21] T.J. Pandian and M.P. Marian, Prediction of assimilation efficiency of Lepidopterans, Proceedings of the Indian Academi of Sciences (Animal Science), 95, 1986, 641-665.

[22] P.S. Yadava, L.K. Vats, and B.R. Kaushal, Food consumption on assimilation and growth in the larvae of Pieris brassicae Linn. Journal of Animal Physiology, 26, 1979, $257-264$.

[23] S.P. Venkata Ramana, J.B. Atluri, and C. Subba Reddi, Autecology of the Common crow butterfly. Ecology, Environment and Conservation, 7(1), 2001, $47-52$.

[24] M. Bhupathi Rayalu, M. Tarakeswara Naidu, J.B. Atluri, and C. Subba Reddi, Life history and larval performance of the Joker butterfly, Byblia ilithyia (Lepidoptera: Rhopalocera: Nymphalidae). Journal of Entomological Society of Iran, 31 (1), 2011 , 71-85.

[25] C.G. Bailey and M.K. Mukerji, Consumption and utilization of various host plants by Melanoplus bivittatus (Say) and M. femurrubrum (DeGeer) (Orthoptera: Acrididae). Canadian Journal of Zoology, 54, 1976, 1044 - 1050.

[26] J. Muthukrishnan, Bioenergetics in insect-plant interactions. Proceedings of Indian Academi of Sciences (Animal Science), 99(3), $1990,243-255$. 